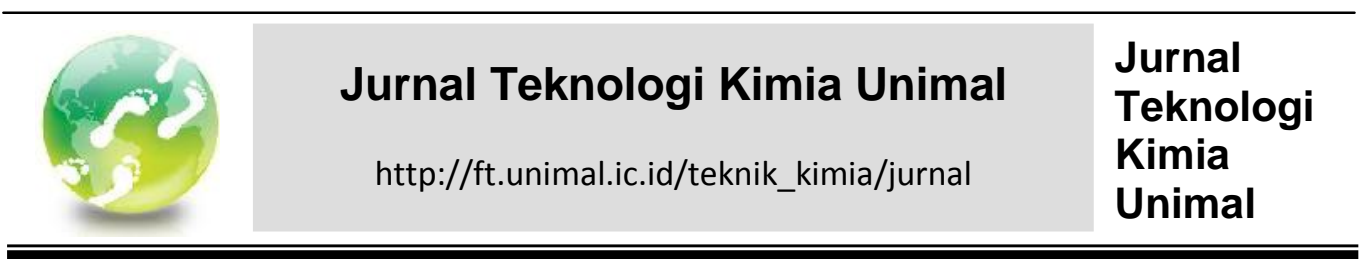

\title{
Pembuatan dan Karakterisasi Gelatin dari Ceker Ayam dengan Proses Hidrolisis
}

\author{
Suryati $^{1}$, Nasrul ZA ${ }^{1}$, Meriatna ${ }^{1}$, Suryani ${ }^{1}$ \\ ${ }^{1}$ Jurusan Teknik Kimia, Fakultas Teknik, Universitas Malikussaleh \\ Laboratorium Teknik Kimia, Jl. Batam No. 2, Bukit Indah, Lhokseumawe 24353 \\ e-mail: ati_ramli@yahoo.com
}

\begin{abstract}
Abstrak
Penelitian ini bertujuan untuk mengkaji proses pembuatan gelatin dari ceker ayam dengan proses hidrolisis asam. Gelatin adalah hidrokoloid yang berasal dari hewan yang berfungsi untuk meningkatkan kekentalan dan pembentuk gel dalam berbagai produk pangan. Proses pengolahan hidrolisis dilakukan dengan variasi perendaman 5 hari, 10 hari dan 15 hari, dengan menggunakan $\mathrm{HCl} 7 \%$ sebagai larutan perendam kaki ayam. Suhu perendaman digunakan dalam penelitian ini adalah $50^{\circ} \mathrm{C}, 60^{\circ} \mathrm{C}, 70^{\circ} \mathrm{C}, 80^{\circ} \mathrm{C}$ dan $90^{\circ} \mathrm{C}$, dengan waktu hidrolisa untuk masing-masing sampel selama 4 jam. Hasil penelitian menunjukkan rendemen tertinggi yang didapat adalah 13,96\%, pada proses perendaman selama 10 hari dengan suhu hidrolisis $90^{\circ}$ C. Kadar air yang terbaik $14,98 \%$ dengan waktu perendaman selama 10 hari dan suhu hidrolisis $60^{\circ} \mathrm{C}$, dan kadar abu yang terbaik $3 \%$ diperoleh dengan perendaman selama 15 hari dan suhu hidrolisis $70^{\circ}$ C. Analisis FTIR menunjukkan adanya serapan khas gugus fungsi gelatin pada daerah Amida A, Amida I, Amida II dan Amida III.
\end{abstract}

Kata Kunci: gelatin, ceker ayam, hidrolisis, kolagen, rendemen

\section{ABSTRACT}

This study aims to assess the process of making gelatine from chicken claw with acid hydrolysis process. Gelatine is a hydrocolloid of animal origin that serves to increase the viscosity and gelling agent in food products. Hydrolysis processing is done by varying the immersion 5 days, 10 days and 15 days, using a solution of $\mathrm{HCl} 7 \%$ as shredded chicken legs. Soaking temperature used in this study is $50^{\circ} \mathrm{C}$, $60^{\circ} \mathrm{C}, 70^{\circ} \mathrm{C}, 80^{\circ} \mathrm{C}$ and $90^{\circ} \mathrm{C}$, with the hydrolysis time for each sample for 4 hours. The results showed the highest yield obtained was $13.96 \%$, in the process of immersion for 10 days at a temperature of $90^{\circ} \mathrm{C}$ hydrolysis. Best water content $14.98 \%$ with a soaking time for 10 days and hydrolysis temperature $60^{\circ} \mathrm{C}$, and the ash content of $3 \%$ is best obtained by soaking for 15 days and hydrolysis temperature of $70^{\circ} \mathrm{C}$. FTIR analysis showed typical absorption functional group Amide A gelatine in the area, I Amida, Amida Amida II and III.

Keywords: gelatine, chicken claw, hydrolysis, collagen, yield 


\section{Pendahuluan}

Gelatin merupakan produk yang diperoleh dari hasil hidrolisis kolagen (protein utama daging/tulang/kulit hewan), sedangkan kolagen diperoleh dari proses ekstraksi kulit, daging, tulang hewan segar. Pemanfaatan gelatin sangat luas seperti sebagai bahan kosmetik, produk farmasi, bahan tambahan pangan (es krim, permen karet, pengental, dan mayonaise), bahan film, material medis, dan bahan baku kultur jasad renik. Secara fisik gelatin berbentuk padat, kering, tidak berasa, dan transparan (Wulandari, 2006).

Menurut data dari SKW Biosystem suatu perusahaan gelatin multinasional bahwa produk gelatin dunia, pada tahun 1999 sebanyak 254.000 ton, yang bersumber dari kulit sapi sebanyak 28,7\%, kulit babi sebanyak 41,4\% serta kontribusi tulang sapi sebesar $29,8 \%$, dan sisanya dari ikan. Gelatin komersial yang ada di pasaran dikategorikan sebagai gelatin tipe A dan tipe B. Pengelompokan ini berdasarkan jenis prosesnya, yaitu proses perendaman asam dan basa. Proses perendaman asam menghasilkan gelatin tipe A dan perendaman basa menghasilkan gelatin tipe B. Gelatin tipe A umumnya berasal dari kulit babi yang memiliki titik isoelektrik (titik pengendapan protein) pada $\mathrm{pH}$ yang lebih tinggi $(7,5-9,0)$, dari $\mathrm{pH}$ isoelektrik gelatin tipe B $(4,8-5,0)$. Sedangkan gelatin tipe B biasanya bersumber dari kulit jangat sapi dan tulang sapi. Sedangkan gelatin ikan dikategorikan sebagai gelatin tipe A. Proses pembuatan gelatin yang berasal dari tulang dapat dilakukan juga dengan menggunakan cara asam yang lebih sederhana yang akhirnya juga menggeser $\mathrm{pH}$ isoelektrik pada sekitar 5,5 - 6,0.

Indonesia merupakan salah satu negara yang mayoritas penduduknya muslim dan gelatin yang beredar di pasaran adalah kebanyakan berbahan dari tulang sapi dan kulit babi, yang mana kulit babi tersebut tidak boleh dikonsumsi oleh seseorang yang beragama Islam. Oleh karena itu penelitian pembuatan 
gelatin berbahan dasar halal terus dikaji agar dihasilkan gelatin yang dapat dan boleh dikonsumsi oleh orang Islam khususnya dan khalayak ramai umumnya.

Ceker ayam (shank) adalah suatu bagian dari tubuh ayam yang kurang diminati, yang terdiri atas komponen kulit, tulang, otot, dan kolagen sehingga perlu diberikan sentuhan teknologi untuk diolah menjadi produk yang memiliki nilai tambah. Berdasarkan data tentang tingginya kandungan protein dalam kulit ayam, maka perlu dilakukannya penelitian selanjutnya untuk mendapatkan gelatin yang berkualitas untuk dapat memenuhi pasar yang ada. Salah satu contoh pemanfaatan kulit ceker ayam yang telah dilakukan oleh Miwada dan Simpen (2007) melalui proses ekstraksi termodifikasi yang diekstraksi dengan campuran kloroform dan metanol. Hasil penelitian yang mereka lakukan menunjukkan bahwa hasil persentase rendemen gelatin yang mereka dapatkan adalah $69,43 \%$, kadar air gelatin adalah $95,77 \%$ dan kadar lemak gelatin adalah 7,99\%. Pada hasil penelitian yang dilakukan dengan metode curing hasil yang didapatkan adalah $99,07 \%$ rendemen, kadar air adalah $66,6 \%$, kadar protein adalah 58,10\%. Dalam metode ini terdapat kelemahan yang diantaranya kulit kaki ayam menjadi kering dan membutuhkan waktu yang lama. Oleh karena itu perlu dilakukan upaya yang dapat mengurangi kelemahan yang dapat mengakibatkan produk yang dihasilkan dapat diterima di pasaran nasional maupun internasional.

Pemanfaatan kulit kaki atau ceker ayam (shank) sebagai bahan baku gelatin perlu dikaji potensinya, mengingat komponen tersebut keberadaannya sangat melimpah yang selama ini pemanfaatannya belum optimal, tetapi memiliki komposisi kimia yang mendukung yakni kadar protein total lebih dari $80 \%$ (Purnomo, 1992). Oleh karena itu dilakukan proses sederhana namun dapat menghasilkan gelatin yang dapat memenuhi pasar nasional dan internasional. Dan proses yang lakukan adalah hidrolisis. Mekanisme reaksi hidrolisis dapat terjadi sebagai berikut:

$$
\begin{array}{ccc}
\mathrm{C}_{102} \mathrm{H}_{149} \mathrm{~N}_{31} \mathrm{O}_{38}+\mathrm{H}_{2} \mathrm{O} & \rightarrow & \mathrm{C}_{102} \mathrm{H}_{151} \mathrm{~N}_{31} \mathrm{O}_{39} \\
\text { Kolagen } & \text { air } & \text { gelatin }
\end{array}
$$


Menurut Johns dan Courts (1977), perubahan kolagen menjadi gelatin terjadi dalam tiga tahap, yaitu: hidrolisa lateral, diikuti hidolisa ikatan peptida terutama pada glysin dan perusakan struktur helik kolagen.

\section{Metode Penelitian}

Bahan-bahan yang digunakan dalam penelitian ini adalah: ceker ayam segar, $\mathrm{NaOH}$ untuk proses degreasing $(5 \%)$ dan untuk netralisasi $0,15 \%, \mathrm{HCl}$ (7\%) dan aquadest. Proses pengolahan hidrolisis dilakukan untuk menghasilkan gelatine dengan variasi suhu $50^{\circ} \mathrm{C}, 60^{\circ} \mathrm{C}, 70^{\circ} \mathrm{C}, 80^{\circ} \mathrm{C}$ dan $90^{\circ} \mathrm{C}$ dan waktu perendaman 5 hari, 10 hari dan 15 hari. Uji yang dilakukan adalah rendemen (\%), kadar air (\%), kadar abu (\%) dan uji gugus fungsi $\left(\mathrm{cm}^{-1}\right)$.

\section{Hasil dan Diskusi}

\section{Rendemen}

Rendeman merupakan persentase berat gelatin yang didapat dari denaturasi kolagen. Semakin besar rendemen yang didapat, maka semakin efisien perlakuan yang diterapkan.

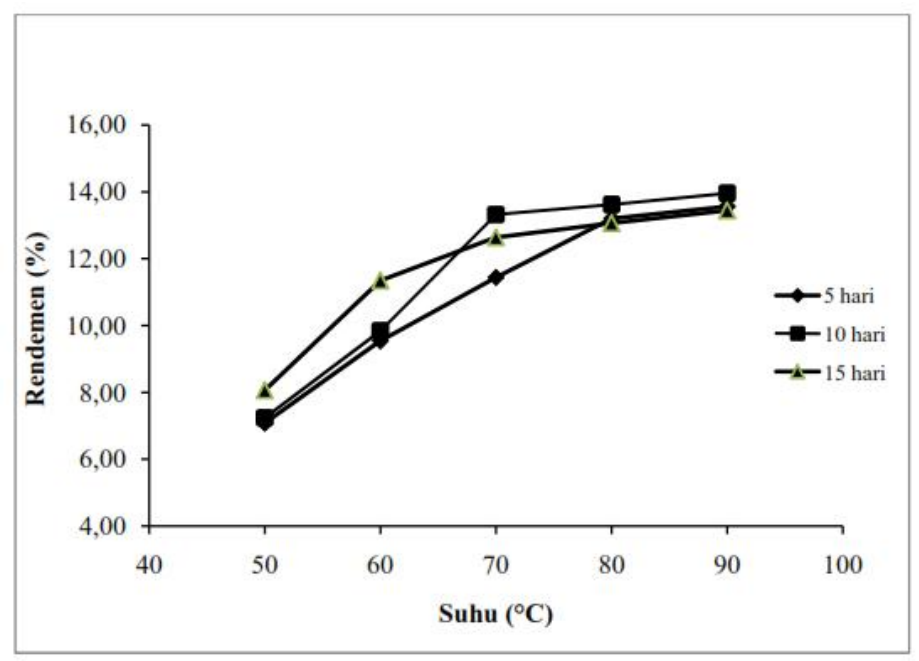

Gambar 1. Pengaruh Suhu hidrolisis terhadap Rendemen Gelatin Ceker Ayam 
Pada Gambar 1 dapat dilihat bahwa rendemen gelatin yang diperoleh pada penelitian ini berkisar antara 7,08-13,96\%. Lama perendaman dalam $\mathrm{HCl}$ berpengaruh terhadap rendemen gelatin yang dihasilkan. Hasil analisis menunjukkan bahwa perendaman dalam $\mathrm{HCl}$ selama 10 hari menghasilkan rendemen tertinggi yaitu 13,96\%. Lama perendaman dalam asam dengan jumlah gelatin yang dihasilkan menunjukkan kecenderungan kenaikan jumlah gelatin dari perendaman 5 hari ke 10 hari. Tetapi apabila waktunya diperpanjang sampai 15 hari, maka terjadi penurunan jumlah gelatin. Hal ini disebabkan karena banyak jaringan fibril kolagen yang rusak dengan peningkatan waktu perndaman sehingga jumlah komponen kolagen yang terlaurt menjadi tinggi, yang berarti rendemen menjadi rendah. Tingginya suhu yang digunakan pada proses hidolisis akan membuat gelatin pecah, yaitu pada suhu lebih dari $75^{\circ} \mathrm{C}$. Komponen kolagen akan terpecah menjadi komponen penyusun nya dan dikategorikan sebagai gelatin kualitas rendah. Pengaruh kenaikan suhu hidrolisis terhadap rendemen gelatin pada masing kadar gelatin berbeda. Semakin tinggi suhu hidrolisis, maka denaturasi kolagen menjadi gelatin akan semakin cepat.

\section{Kadar Air}

Kadar air merupakan salah satu parameter dalam pengujian daya simpan produk, terutama produk-produk pangan yang bersifat kering. Kadar air standar bagi gelatin komersil adalah maksimal 16\%. Analisa yang dilakukan terhadap kadar air bertujuan untuk mengetahui kandungan kadar air dalam gelatin. Jika kadar air yang terkandung dalam bahan, maka dapat mempengaruhi penampakan, tekstur produk dan daya simpannya (Winaryo, 1992).

Berdasarkan Gambar 2 terlihat bahwa kadar air yang paling rendah didapatkan pada hidrolisis dengan suhu $60^{\circ} \mathrm{C}$ dengan lama perendaman selama 10 hari, yaitu $14,98 \%$, dan kadar air paling tinggi terdapat pada suhu hidrolisis $90^{\circ} \mathrm{C}$, dengan lama perendaman selama 15 hari, yaitu 16,19\%. Kadar air dalam gelatin akan meningkat dengan semakin tingginya suhu hidrolisis, hal ini disebabkan oleh termobilisasinya air di dalam struktur jaringan protein. Berdasarkan SNI (1995), kadar air yang boleh kandung dalam gelatin adalah maksimum 16\%. Maka, dari 
hasil yang didapatkan terdapat beberapa hasil yang kadar airnya melebihi kadar maksimum yang ditentukan.

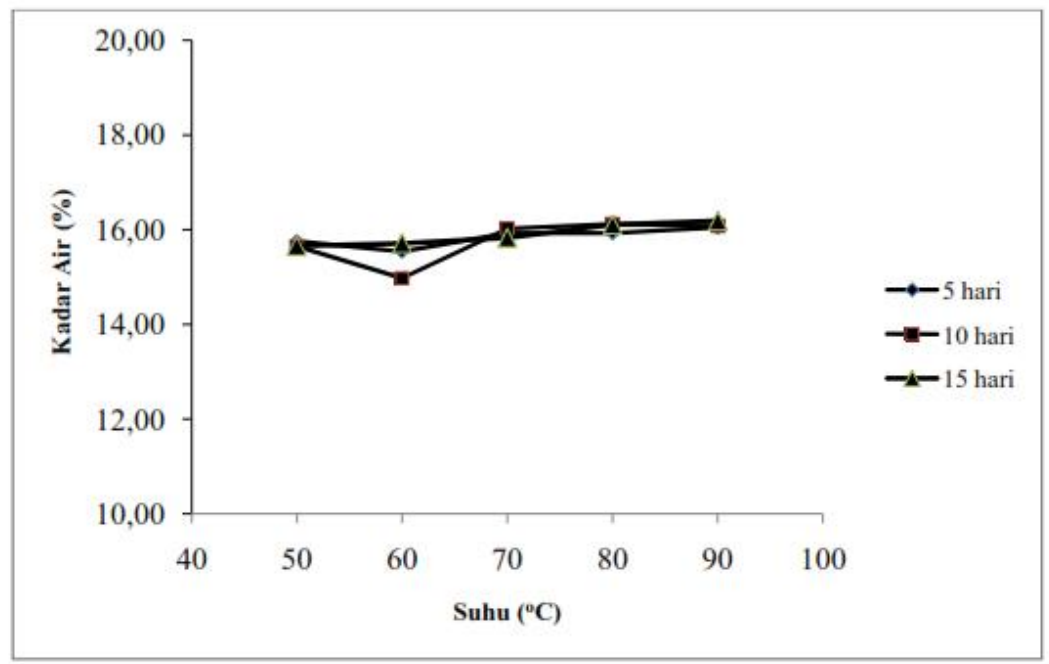

Gambar 2 Pengaruh Suhu Hidrolisis Terhadap Kadar Air Gelatin Ceker Ayam

\section{Kadar Abu}

Kadar abu merupakan residu anorganik dari pembakaran bahan-bahan organik dan biasanya komponen-komponen tersebut terdiri dari kalsium, natrium, besi magnesium dan mangan. Abu yang terbentuk berwarna putih abu-abu, berpartikel halus dan mudah dilarutkan. Kadar abu menunjukkan kemurnian produk, yang dipengaruhi pula oleh kandungan mineral bahan baku. Kadar abu gelatin yang dibolehkan adalah maksimum 3,25\%.

Berdasarkan Gambar 3, lama waktu perendaman tidak menjadi tolak ukur terhadap tinggi rendahnya kadar abu. Kadar abu yang diperoleh dari penelitian berkisar antara 3-3,52\%. Kadar abu yang paling rendah terdapat pada suhu hidrolisis $70^{\circ} \mathrm{C}$ dengan lama perendaman selama 15 hari, yaitu $3 \%$, dan kadar abu yang paling tinggi terdapat pada suhu hidrolisis $50^{\circ} \mathrm{C}$ dengan lama perendaman selama 5 hari, yaitu 3,52\%. Kadar abu yang didapatkan ini adalah melebihi Standar Nasional Indonesia (SNI) 1995, yang mana maksimum kadar abu yang dibolehkan adalah 3,25\%. Tingginya kadar abu gelatin yang dihasilkan dipengaruhi oleh kandungan mineral bahan baku, tergantung pada proses penyaringan dan hidrolisis yang dilakukan. Penyaringan yang kurang sempurna 
menyebabkan banyak serbuk ossein yang terbawa dalam filtrat gelatin. Serbuk ossein yang halus lolos dari saringan, membentuk endapan pada saat gelatin diubah menjadi gel.

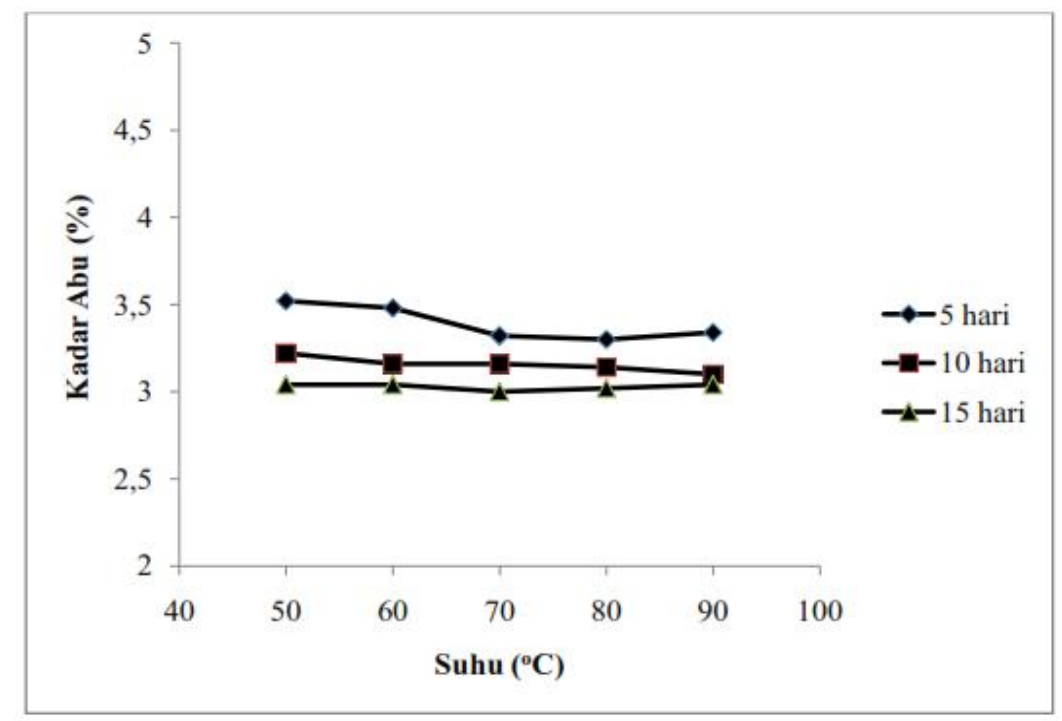

Gambar 3 Pengaruh Suhu hidrolisis Terhadap Kadar Abu Gelatin Ceker Ayam

\section{Uji FTIR (Fourier Transform Infra Red)}

Untuk membuktikan bahwa hasil penelitian ini adalah gelatin, maka dilakukan karakterisasi serapan gugus fungsi khas gelatin dengan FTIR. Setiap gugus fungsi yang berbeda, seperti $\mathrm{O}-\mathrm{H}, \mathrm{C}-\mathrm{H}$, atau $\mathrm{C}=\mathrm{C}$, menyerap dalam range atau frekuensi yang sempit, sehingga gugus fungsi dalam molekul dapat diidentifikasi melalui adanya pita serapan dalam range tertentu pada spektrum inframerah.

Gelatin seperti umumnya protein memiliki struktur terdiri dari karbon, hidrogen, gugus hidroksil $(\mathrm{OH})$, gugus karbonil $(\mathrm{C}=\mathrm{O})$ dan gugus amina $(\mathrm{NH})$. Spektra infra merah (Gambar 4) menunjukkan bilangan gelombang 2927,1 $\mathrm{cm}^{-1}$ dan 2854,77 $\mathrm{cm}^{-1}$, dimana panjang gelombang ini disebut dengan Amida A. Menurut Kemp (1987), puncak ini menunjukkan bahwa gugus NH dalam amida akan cenderung berikatan dengan regangan $\mathrm{CH}_{2}$ apabila gugus karboksilat dalam keadaan stabil. Pada gugus gelatin selanjutnya adalah Amida I. Puncak serapan 
pada frekuensi 1636-1661 $\mathrm{cm}^{-1}$ yang disebut sebagai kurva serapan Amida I (Muyongga, dkk, 2004). Serapan ini disebabkan oleh adanya regangan ikatan ganda gugus karbonil $\mathrm{C}=\mathrm{O}$, bending ikatan $\mathrm{NH}$ dan regangan $\mathrm{CN}$. Daerah serapan Amida I ini menunjukkan adanya regangan $\mathrm{C}=\mathrm{O}$ dan gugus $\mathrm{OH}$ yang berpasangan dengan gugus karboksil. Daerah serapan 1660-1650 cm-1 dikenal sebagai daerah serapan residu imida (struktur random coil) dan pada $1635-1645 \mathrm{~cm}^{-1}$ meruapakan residu struktur $\beta$-sheet (Prystupa dan Donald, 1996). Pada kurva amida I Gambar 4 ditutupi oleh puncak $\mathrm{C}=\mathrm{O}$ streching/ikatan hidrogen yang bergandengan dengan COO-, dengan spektra 1744,69 $\mathrm{cm}^{-1}$ Streching ini menandakan regangan dalam ikatan sehingga terjadinya perubahan jarak dan akan bergerak terus seiring dengan suhu tinggi.

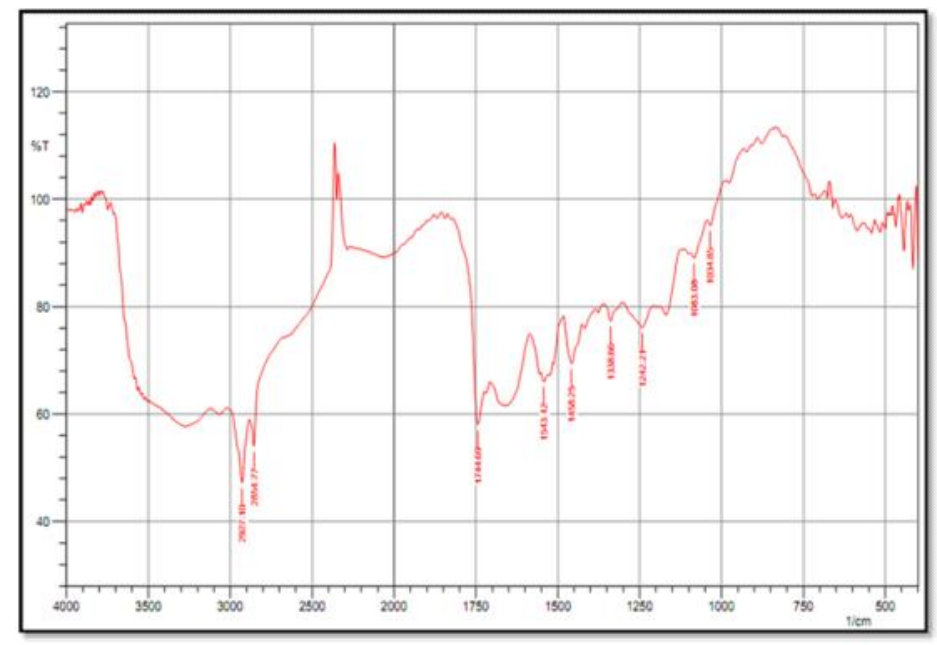

Gambar 4 Spektra dengan waktu perendaman 5 hari dan suhu hidrolisis $50^{\circ} \mathrm{C}$

Pada Gambar 5, spektra yang ditunjukkan oleh puncak serapan adalah $1665 \mathrm{~cm}^{-1}$ yang menandakan bahwa puncak serapan tersebut masuk dalam struktur random coil yang menjadi gugus khas gelatin (Prystupa dan Donald, 1996).

Puncak serapan khas gelatin pada kurva amida II yaitu pada spektra 1335$1560 \mathrm{~cm}^{-1}$ (Muyongga, dkk., 2004). Vibrasi amida II disebabkan oleh deformasi ikatan N-H dalam protein. Daerah serapan ini berikatan dengan deformasi 
tropokolagen menjadi rantai $\alpha$-helix. Pada gambar-gambar diatas spektra yang ditunjukkan oleh serapan puncak menandakan bahwa salah satu gugus khas gelatin ada pada hasil yang didapat.

Daerah serapan spesifik terakhir adalah amida III. Puncak serapannya adalah 1200-1300 $\mathrm{cm}^{-1}$ (Muyongga, dkk., 2004), yang berhubungan dengan struktur triple-helix (kolagen).

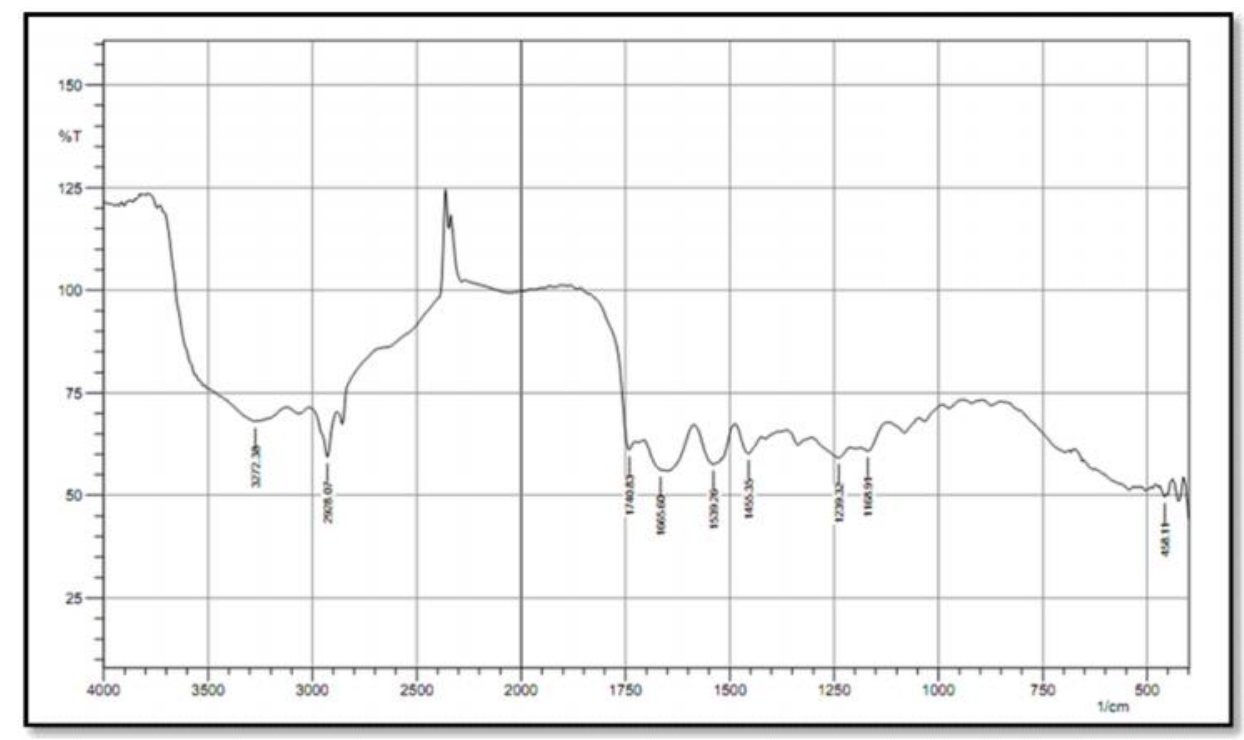

Gambar 5 Spektra dengan perendaman 5 hari dan suhu hidrolisis $60^{\circ} \mathrm{C}$

Pada kurva serapan amida A, Gambar 6 menunjukkan serapan melebar pada spektra $3272,38 \mathrm{~cm}^{-1}$. Puncak serapan ini disebabkan oleh adanya ikatan regangan $\mathrm{N}-\mathrm{H}$ dari gugus amida yang berasosiasi dengan ikatan hidrogen, dan adanya gugus $\mathrm{OH}$. Bentuk puncak yang melebar membuktikan adanya gugus hidroksiprolin. Pada puncak serapan untuk amida I menunjukkan spektra 1742,76 $\mathrm{cm}^{-1}$. Menurut Muyongga (2004), puncak serapan amida I yang melebar ke arah amida $\mathrm{A}$ adalah gugus $\mathrm{C}=\mathrm{O}$ streching/ ikatan hidrogen yang bergandengan dengan COO-. Spektra yang $1526,72 \mathrm{~cm}^{-1}$ menunjukkan vibrasi amida II yang disebabkan oleh deformasi ikatan N-H dalam protein. Daerah serapan ini berkaitan dengan deformasi rantai $a$-helix.. Daerah spesifik untuk amida III adalah 1200-1300 cm-1 (Fries and Lee, 1996) yang berhubungan dengan struktur triple-helix (kolagen). 
Pada Gambar 6 menunjukkan serapan 1237,39 cm-1, pada spektra ini menunjukkan bahwa masih ada struktur kolagen yang belum terdenaturasi menjadi gelatin dan lolos dalam proses penyaringan, dapat dikatakan bahwa ikatan hidrogen intermolekul masih banyak berikatan pada gugus tersebut.

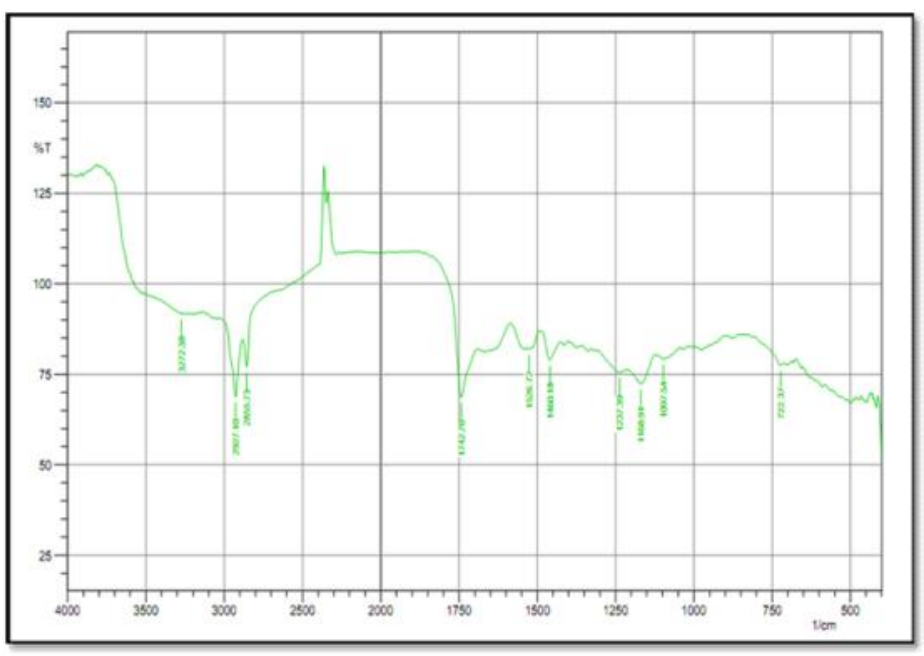

Gambar 6 Spektra dengan perendaman 10 hari dan suhu hidrolisis $70^{\circ} \mathrm{C}$

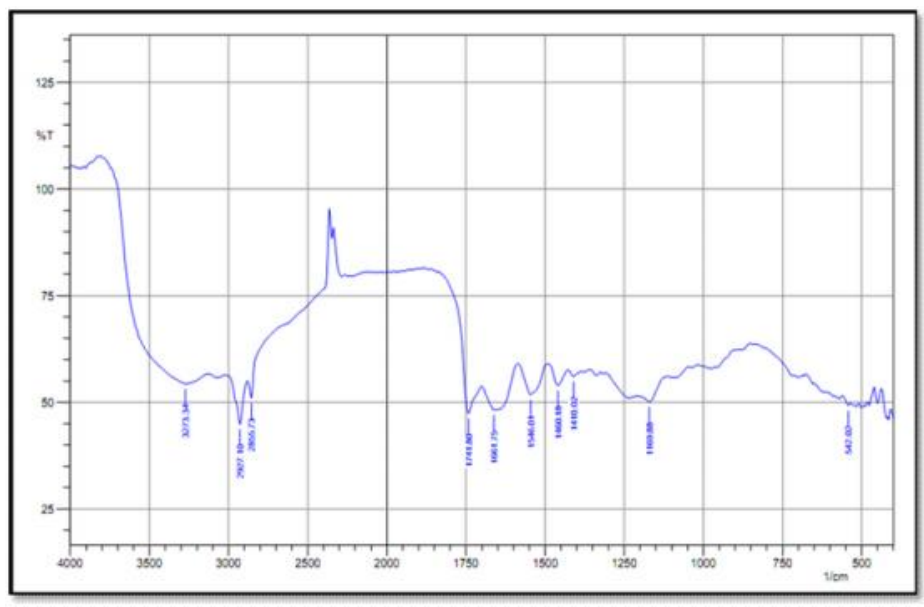

Gambar 7 Spektra dengan perendaman 15 hari dan suhu hidrolisis $80^{\circ} \mathrm{C}$

Puncak serapan yang ditunjukkan oleh Gambar 7 adalah $3273,34 \mathrm{~cm}^{-1}$, pada puncak ini menunjukkan vibrasi streching $\mathrm{OH}$ dengan serapan yang melebar. Puncak ini disebabkan oleh adanya ikatan regangan $\mathrm{N}-\mathrm{H}$ dari gugus amida yang 
berasosiasi dengan ikatan hidrogen. Bagian amida A selanjutnya adalah serapan pada puncak 2927,10 $\mathrm{cm}^{-1}$ dan $2855,73 \mathrm{~cm}^{-1}$, menurut Kemp (1987), puncak ini menunjukkan bahwa gugus NH dalam amida akan cenderung berikatan dengan regangan $\mathrm{CH}_{2}$ apabila gugus karboksilat dalam keadaab stabil. Pada amida I, puncak serapan adalah $1661,75 \mathrm{~cm}^{-1}$, yang mana serapan ini disebabkan oleh adanya regangan ikatan ganda gugus karbonil $\mathrm{C}=\mathrm{O}$, bending ikatan $\mathrm{NH}$ dan regangan CN. Daerah serapan amida II adalah puncak serapan pada $1560-1335^{\mathrm{cm}-1}$ (Muyongga, 2004). Vibrasi amida II pada spektra diatas menunjukkan kurva pada $1546,01 \mathrm{~cm}^{-1}, 1460,18^{\mathrm{cm}-1}$ dan $1410,02^{\mathrm{cm}-1}$. Daerah serapan ini berkaitan dengan deformasi tropokolagen menjadi rantai- $\alpha$. Daerah serapan yang terakhir adalah amida III, yang puncak serapannya adalah $1240-670^{\mathrm{cm}-1}$ dan berhubungan dengan triple-helix (Hashim, dkk., 2009). Gugus tersebut adalah gugus yang berkaitan dengan kolagen, yang berarti masih ada sebagian struktur kolagen yang belum terhidrolisa menjadi gelatin dan lolos saat dilakukannya penyaringan gelatin.

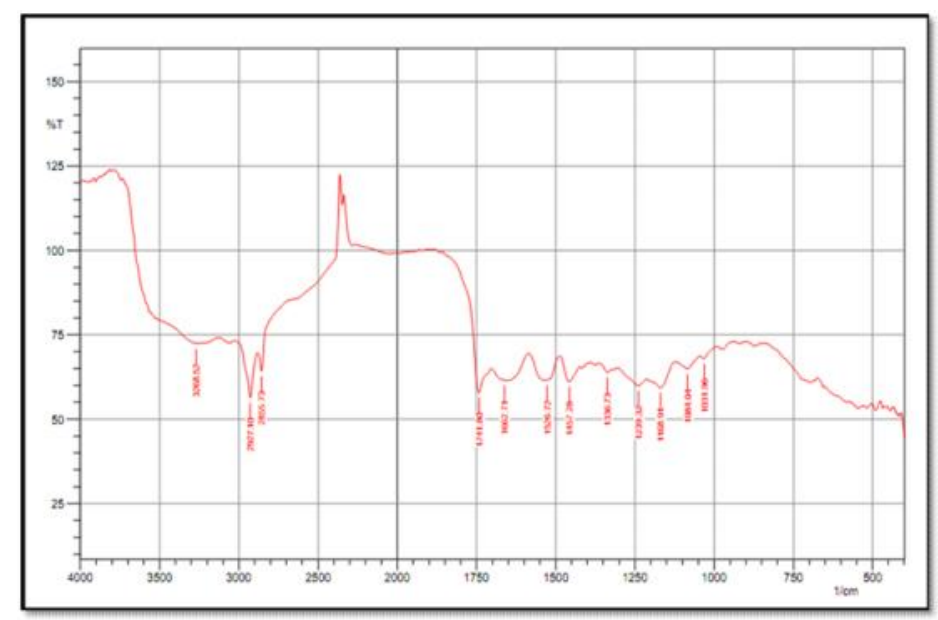

Gambar 8 Spektra dengan perendaman 15 hari dan suhu hidrolisis $90^{\circ} \mathrm{C}$

Spektra infra merah (Gambar 8) menunjukkan bending dan streching $\mathrm{CH}$ ditunjukkan pada daerah 3000-2800 $\mathrm{cm}^{-1}$ ditunjukkan oleh panjang gelombang $3265,52 \mathrm{~cm}^{-1}, 2854,77 \mathrm{~cm}^{-1}$ dan $2855,73 \mathrm{~cm}^{-1}$ yang mana panjang gelombang ini disebut dengan Amida A dengan bentuk kurva yang lebar. Kebanyakan puncak NH yang diserap mempunyai bentuk yang tajam dan sempit. Oleh karena itu, 
puncak yang diserapn sebenarnya membuktikan adanya gugus $\mathrm{OH}$. Pada serapan amida I spektra yang ditunjukkan adalah 1741,80 cm-1 dan 1662,71 cm-1, hal ini menunjukkan adanya serapan regangan $\mathrm{C}=\mathrm{O}$ karbonil asam karboksilat yang disebabkan oleh proses perendaman dengan asam. Gugus khas gelatin selanjutnya adalah amida II $1526,72 \mathrm{~cm}^{-1}, 1457,28 \mathrm{~cm}^{-1}$ dan $1336,73 \mathrm{~cm}^{-1}$, pada panajng gelombang ini berkaitan dengan deformasi tropokolagen menjadi rantai $\alpha$-helix. Serapan panjang gelombang yang terakhir adalah amida III yang ditunjukkan oleh panjang gelombang 1239,32 $\mathrm{cm}^{-1}, 1165,91 \mathrm{~cm}^{-1}, 1084,04 \mathrm{~cm}^{-1}$ dan 1031,96 $\mathrm{cm}^{-1}$, panjang gelombang yang ditunjukkan oleh Gambar 8 pada amida III bervibrasi dengan dengan regangan $\mathrm{C}-\mathrm{O}$ dari rantai pendek peptida yang terjadi karena degradasi rantai peptida.

\section{Simpulan}

Berdasarkan analisis yang telah dilakukan dapat diambil kesimpulan sebagai bahwa ceker ayam (shank) dapat digunakan sebagai alternatif bahan baku pengganti tulang sapi dan babi dalam pembuatan gelatin. Rendemen tertinggi yang didapat adalah $13,96 \%$ yang didapatkan pada proses perendaman selama 10 hari dengan suhu hidrolisis $90^{\circ} \mathrm{C}$. Kadar air terendah pada perendaman selama 10 hari dan suhu hidrolisis $60^{\circ} \mathrm{C}$, dengan kadar $14,98 \%$. Kadar abu tere ndah adalah pada perendaman selama 15 hari dan suhu hidrolisis $70^{\circ} \mathrm{C}$ dengan kadar $3 \%$. Hasil uji FTIR menunjukkan adanya serapan khas gugus fungsi gelatin pada daerah Amida A, Amida I, Amida II dan Amida III.

\section{Daftar Pustaka}

1. Arthadana, L. N. 2001. Kajian Proses Produksi Gelatin Tipe A Berbahan Kulit Sapi dengan Metode Perendaman Asam. Skripsi. Departemen Teknologi Industri Pertanian. Fakultas Teknologi Pertanian. IPB. Bogor.

2. Astawan, M dan T. Aviana. 2003. Pengaruh Jenis Larutan Serta Metode Pengeringan Terhadap Sifat Fisik, Kimia Dan Fungsional Gelatin Dari Kulit Ikan Cucut. Jurnal Teknologi dan Industri Pangan., Vol. XIV No. 1: 7-13. 
3. Chaplin, M. 2005. Gelatin. www//isbuc.ac.uk Chen, H. 1995. Functional Properties And Applications Of Edible Films Made Of Milk Proteins. J. Of Dairy Sci., 78(11): 2563-2583.

4. Friess, W., and Lee, G., 1996, Basic thermoanalytical studies of insoluble collagen matrices, Biomaterials, 17 (23) : 2289-2294.

5. Grobben, A.H.; P.J. Steele; R.A. Somerville; and D.M. Taylor. 2004. Inactive of The Bovine-Spongiform-Encephalopathy (BSE) Agent by Acid and Alkali Processes Used The Manufacture of Bone Gelatine. Biotechnology and Applied Biochemistry, 39:329 - 338.

6. Hardinsyah dan Drajat, M. (1989). Menaksir Kecukupan Energi dan Protein serta Penilaian Mutu Gizi Konsumsi Pangan. Cetakan Pertama. Jakarta: Wirasari.

7. Jackson, M., Choo, L. P., Watson, Halliday, W. C., and Mantsch, H. H., 1995, Beware of connective tissue proteins: assignment and implications of collagen absorption in infrared spectra of human tissues, Biochimica et Biophysica Acta-Molecular Basic of Disease, 1270 : 1-6.

8. Kusumawati, Rinta. 2008. Pengaruh Perendaman dalam Asam Klorida Terhadap Kualitas Gelatin Tulang Kakap Merah (Lutjanus Sp). Jurnal Pascapanen Dan Bioteknologi Kelautan dan Perikanan.

9. M.N., Puspawati, dkk. ISSN 1907-9850. Isolasi Gelatin dari Kulit Kaki Ayam Broiler dan Karakteristik Gugus Fungsinya dengan Spektrofotometri FTIR. Jurnal kimia 6 (1), januari 2012 : 79-87.

10. Montero, P; and M.C. Gomez-Guillen. 2000. Extracting Condition for Mergin (Lepidorhombus boscii) Skin Collagen Affect Functional Properties of Resulting Collagen. Jurnal of Food Science, 55(2) 1-5.

11. Muyonga, J. H., Cole, C. G. B., and Duodu K. G., 2004, Extraction and physicochemical characterisation of Nile perch (Lates niloticus) skin and bone gelatin, Food Hydrocolloids, 18 (4) : 581-592.

12. Prystupa, D. A. and Donald, A. M. 1996. Infrared study of gelatin conformations in gel and sol states, Polymer Gels and Networks. 4 : 87110 .

13. SNI 06-3735-1995. Mutu dan Cara Uji Gelatin. Badan Standardisasi Nasional. Jakarta. p.1-2.

14. Wiyono, V.S. 2001. Gelatin Halal Gelatin Haram. Jurnal Halal LPPOMMUI No. 36. 
Suryati dkk / Jurnal Teknologi Kimia Unimal 4 : 2 (November 2015) 66 - 79

15. Wulandari, D. 2006. Ekstraksi Dan Karakteristik Gelatin Dari Kulit Kaki Ayam.Program Studi Ilmu Peternakan. Tesis. Sekolah Pascasarjana UGM, Yogyakarta. 